\title{
PENAMPILAN PERTUMBUHAN AYAM BANGKOK STARTER YANG DIBERI PAKAN DENGAN LEVEL PROTEIN BERBEDA
}

\author{
Aditya R. Mokodongan, F. Nangoy, Jein Rinny Leke*, Zulkifli Poli \\ Fakultas Peternakan Universitas Sam Ratulangi Manado
}

\begin{abstract}
ABSTRAK
Penelitian ini bertujuan untuk mengetahui sampai sejauh mana pemberian pakan dengan level protein berbeda terhadap penampilan pertumbuhan ayam bangkok starter. Materi yang digunakan dalam penelitian ini adalah 36 ekor ayam berumur 2 minggu. Perlakuan yang digunakan adalah Ransum A dengan level protein $18 \%$, Ransum B dengan level protein 20\%, Ransum C dengan level protein $22 \%$. Variabel yang diamati meliputi Konsumsi ransum (g/ekor/hari), pertambahan berat badan (g/ekor/hari), konversi ransum dan mortalitas (\%). Metode penelitian yang digunakan adalah metode percobaan menggunakan Rancangan Acak Lengkap (RAL) dengan menggunakan 3 perlakuan dengan 6 ulangan dan tiap ulangan terdiri dari 2 ekor ayam Bangkok. Hasil Penelitian menunjukkan bahwa pemberian pakan dengan level protein berbeda tidak berpengaruh nyata $(\mathrm{P}>0.05)$ terhadap konsumsi ransum, pertambahan berat badan, konversi ransum dan mortalitas. Berdasarkan hasil penelitian dapat disimpulkan bahwa pemberian pakan dengan level protein $18-22 \%$ pada ayam bangkok fase starter memberikan hasil yang sama terhadap konsumsi ransum, pertambahan berat badan, serta konversi ransum.
\end{abstract}

*Korespondensi (corresponding Author) Email : rinileke@yahoo.com
Kata Kunci : Ayam Bangkok, Penampilan Pertumbuhan, Level protein.

\section{ABSTRACT}

$\begin{array}{lrr}\text { THE } & \text { GROWTH } & \text { OF } \\ \text { PERFORMANCE } & \text { "BANGKOK" } \\ \text { CHICKEN AT THE STARTER PHASE } \\ \text { GIVEN FEED IN LEVELS OF } \\ \text { DIFFERENCE PROTEIN. This study }\end{array}$
was conducted to evaluate the levels of protein in ration affecting consumption, average daily gain, feed conversion and mortality of "Bangkok" chicken at the starter phase. Birds used in this study were 36 chicken at the age of 2 weeks old. Treatments in this study were rations with protein levels of 18 percents (Ration A), 20 percents (Ration B), and 22 percents (Ration C).Variables observed were feed consumption $(\mathrm{g} / \mathrm{h} / \mathrm{d})$, Average daily gain $(\mathrm{g} / \mathrm{h} / \mathrm{d})$, feed conversion and mortality (percents). Method of completely randomized design were applied in this study using 3 treatments with 6 replications at each treatment. Each treatment and replication was filled 2 chicken of "Bangkok" strain. Results of this study showed that protein levels of 18 to 22 percents in the diets did not affect feed consumption, average daily gain, feed conversion and mortality. Therefore, it can be concluded that the protein levels of 18 to 22 percents in the diets had the same responses in growing performance of "Bangkok" strain at starter phase.

Kata Kunci:"Bangkok" strain chicken, growing performance, protein levels. 


\section{PENDAHULUAN}

Ayam bangkok umumnya dipelihara sebagai ayam aduan,ayam tersebut diintroduksi dari pulau jawa, kemudian telah lama dikembangkan di Sulawesi Utara harga ayam bangkok jantan sangatlah tinggi dibandingkan dengan ayam kebanyakan. Peternak umumnya memelihara ayam bangkok secara khusus dan pertumbuhan sebagai ayam aduan dalam perkembangan pemberian bahan ransum sesuai dengan fase pertumbuhan. Salah satu kriteria diantaranya adalah ayam berbobot badan tinggi,agar ayam lebih kuat melakukan penyerangan dan pertahanan dari serangan lawan. Morfologi ayam bangkok umumnya lebih besar dan kekar dari pada ayam kampung pada umumnya,sehingga disamping dimanfaatkan sebagai ayam aduan, ayam ini bisa dimanfaatkan untuk meningkatkan pertumbuhan ayam kampung melalui persilangan. Penampilan pertumbuhan ayam bangkok dapat dilakukan melalui perbaikan kuantitas dan kualitaspakan yang diberikan. Pakan berkualitas harus mengandung zat - zat nutrisi yang dibutuhkan sesuai dengan perkembangan umur dan tujuan pemeliharaan, pakan yang sempurna dengan kandungan zat-zat nutrisi yang seimbang akan memberikan hasil yang optimal.
Performans ayam bangkok sangatlah ditentukan oleh penanganan mulai dari DOC, masa starter, grower dan dewasa. Fase-fase inilah diperlukan pakan yang berkualitas dan diberikandalam kuantitas yang cukup sehingga performansnya muncul dalam keadaan maksimal. Berdasarkan hal di atas maka telah dilakukan suatu penelitian untuk mengetahui sejauh mana performan ayam bangkok fase starter yang di berikan pakan dengan level protein yang berbeda.

\section{MATERI DAN METODE PENELITIAN}

Meteri yang digunakam dalam penelitian ini adalah ayam bangkok berumur 2 minggu sebanyak 35 ekor. Kandang yang digunakan 18 unit kandang baterai, dengan masing cage berukuran 30 x 35 x $35 \mathrm{~cm}$ dan setiap unit kandang ditempati 2 ekor ayam bangkok kandang juga dilengkapi dengan tempat makan dan minum. Perlakuan menggunakan 3 jenis pakan dengan level protein yang berbeda. Pakan yang digunakan dalam penelitian yaitu jagung, dedak halus, Cp 591, Tepung Ikan, Tepung Kedelei, dan Top Mix.3. Level protein berbeda yang diberikan pada masing masing perlakuan yang dimaksud yaitu :

1. Ransum A dengan level protein $18 \%$

2. Ransum B dengan level protein $20 \%$ 
Tabel 1. Kandungan Nutrien Bahan Pakan Penyusun Ransum Perlakuan A dan C

\begin{tabular}{lcccccc}
\hline \multicolumn{1}{c}{ Bahan Pakan } & $\begin{array}{c}\text { Protein } \\
(\boldsymbol{\%})\end{array}$ & $\begin{array}{c}\text { EM } \\
(\mathbf{K k a l} / \mathbf{k g})\end{array}$ & $\mathbf{S K}(\boldsymbol{\%})$ & $\begin{array}{c}\text { Lemak } \\
(\boldsymbol{\%})\end{array}$ & $\begin{array}{c}\text { Ca } \\
(\boldsymbol{\%})\end{array}$ & $\begin{array}{c}\text { P } \\
(\boldsymbol{\%})\end{array}$ \\
\hline Jagung $^{*}$ & 9,42 & 3182 & 2,15 & 5,17 & 0,22 & 0,6 \\
Dedak Halus *** $^{*}$ & 9,9 & 3100 & 12,83 & 6,06 & 0,68 & 0,78 \\
Cp 591* & 20 & 3000 & 6 & 3 & 0,9 & 0,6 \\
Tepung ikan*** & 50,56 & 2820 & 3,9 & 2,83 & 3,1 & 1,88 \\
Tepung kedelai*** & 39,56 & 2850 & 7,34 & 1,67 & 0,3 & 0,18 \\
Top mix & - & - & - & - & 5,38 & 1,44 \\
\hline
\end{tabular}

Sumber : * Laboratorium Ruminansia dan Kimia Makanan Ternak FAPET UNPAD, 2013. ** PT. Charoen Pokphand Indonesia. *** Hasil analisa : Leke J.R.(2013)

Tabel 2. Formulasi Bahan Pakan Perlakuan

\begin{tabular}{|c|c|c|c|}
\hline \multirow{2}{*}{ Bahan Pakan } & \multicolumn{3}{|c|}{ Perlakuan` } \\
\hline & A & $\mathrm{B}$ & $\mathrm{C}$ \\
\hline Jagung* & 10 & - & 18 \\
\hline Dedak & 5 & - & 4 \\
\hline Cp 591** & 83 & 100 & 56 \\
\hline Tepung ikan & - & - & 8 \\
\hline Tepung kedelai & - & - & 12 \\
\hline Top mix & 2 & - & 2 \\
\hline Jumlah & 100 & 100 & 100 \\
\hline
\end{tabular}

Tabel 3. Kandungan Zat-Zat Makanan Ransum Penilitian

\begin{tabular}{lccc}
\hline \multirow{2}{*}{ Kandungan zat makanan } & \multicolumn{3}{c}{ Perlakuan } \\
\cline { 2 - 4 } & $\mathrm{A}$ & $\mathrm{B}$ & $\mathrm{C}$ \\
\cline { 2 - 4 } & 18,04 & 20 & 22 \\
\hline Protein & 5,84 & 6 & 5,45 \\
SK & 3,31 & 3 & 3,28 \\
Lemak & 0,91 & 0,09 & 0,96 \\
Ca & 0,63 & 0,6 & 0,68 \\
P & 2963,2 & 3000 & 2944,36 \\
Energi Metablois(Kkal/kg) & & & \\
\hline
\end{tabular}

3. Ransum C dengan level protein $22 \%$.

Pakan yang digunakan dapat dilihat pada Tabel 1,2 dan 3 . 
Metode penelitian yang digunakan adalah rancangan acak lengkap dengan 3 perlakuan dan 6 ulangan dan tiap ulangan berisi dua ekor ayam bangkok. Sedangkan penggunaan sesuai dengan perlakuan adalah ransum A dengan level protein $18 \%$, ransum B dengan level protein 20\%, ransum $\mathrm{C}$ dengan level protein $22 \%$. Pakan yang digunakan dapat dilihat pada Tabel 1,2 dan 3. Variabel yang diamati meliputi :

\section{Konsumsi Ransum}

Dihitung berdasarkan jumlah ransum yang diberikan (g/ekor/hari), dikurangi dengan jumlah ransum yang tersisa (g/ekor/hari) (Anggorodi, 1990). Konsumsi ransum = ransum yang diberikan - ransum yang tersisa

\section{Pertambahan Berat Badan}

Dihitung berdasarkan selisih antara berat badan akhir $(\mathrm{g})$, dengan berat badan awal dilakukan setiap minggu (Tilman et al., 1991). Pertambahan Berat Badan $=\mathrm{BB}$ akhir (g) -BB awal (g)

\section{Konversi Ransum}

Dihitung berdasarkan perbandingan antara konsumsi ransum dengan pertambahan berat badan (Rasyaf, 2009).

Konversi Ransum = $\frac{\text { Konsumsi Ransum }}{\text { Pertambahan berat badan }} \times 100 \%$

\section{Mortalitas}

Jumlah ayam yang mati (mortalitas) dengan jumlah ayam yang dipelihara (Lacy dan Vest 2000).

\section{Analisis Data \\ Data secara statistik dengan menggunakan analisis ragam Rancangan Acak Lengkap. Apabila terdapat perbedaan diantara perlakuan dilakukan uji lanjut dengan Duncan's menurut Steel and Torrie, 1984.}

\section{HASIL DAN PEMBAHASAN}

\section{Pengaruh Perlakuan Terhadap Konsumsi Ransum}

Hasil pengamatan pengaruh perlakuan terhadap konsumsi ransum selamapenelitian dapat dilihat pada Tabel 4.

Konsumsi ransum adalah jumlah ransum yang dikonsumsi oleh ternak dalam satuan waktu tertentu. Rataan konsumsi ransum selama penelitian dapat dilihat pada Tabel 5 menunjukan bahwa rataan konsumsi ransum tertinggi dicapai pada perlakuan RB sebesar 102,01 gr/ekor/hari, sedangkan yang terendah dicapai pada perlakuan RA sebesar 92,74 gr/ekor/hari. Kholik (2016) menyatakan bahwa performan ayam hasil persilangan pejantan bangkok dengan betina ras petelur strain 
Tabel 4. Rataan Konsumsi Ransum, Pertambahan Berat Badan, Konversi Ransum (gram/ekor/hari) selama penelitian.

\begin{tabular}{lcccc}
\hline Variabel & \multicolumn{3}{c}{ Perlakuan } & Total \\
\cline { 2 - 4 } & RA & RB & RC & \\
\hline Konsumsi (g /ekor/hari) & 92,74 & 102,01 & 93,96 & 288,71 \\
PBB (g /ekor/hari) & 62,38 & 75,52 & 64,34 & 202,25 \\
Konversi ransum & 1,50 & 1,34 & 1,46 & 4,31 \\
\hline Kennnnnn
\end{tabular}

Keterangan: Rataan konsumsi ransum, pertambahan berat badan dan konversi ransum menunjukan tidak berbeda nyata $(\mathrm{P}>0,05)$.

$\mathrm{RA}=$ Ransum $\mathrm{A}$ dengan level protein $18 \%, \mathrm{RB}=$ Ransum $\mathrm{B}$ dengan level protein $20 \%, \mathrm{RC}=$ Ransum $\mathrm{C}$ dengan level protein $22 \%$

lohman, konsumsi ransum untuk pejantan umur 8 minggu 90,21 gr/ekor/hari sedangkan untuk betina 70,96 gr/ekor/hari. Fahrudin (2017) mengemukakan bahwa konsumsi ransum ayam lokal di jimmy farm sebesar 1846,68 gram per ekor atau 29,31 g/ekor/hari selama satu kali periode pemeliharaan (52 - 72 hari), dengan nilai minimal dan maksimal masing masing 1262,81 g dan 2255,88 gram dengan protein kasar $16-18 \%$.

Hasil analisis keragaman menunjukan bahwa ketiga macam ransum dengan level protein berbeda memberikan pengaruh yang tidak berbeda nyata $(\mathrm{P}>0,05)$. Hal ini disebabkan karena pemberian tiga macam pakan dengan level protein berbeda tidak menyebabkan perbedaan konsumsi ransum pada ayam bangkok, disebabkan kandungan zat - zat makanan termasuk energi dan protein yang diberikan untuk setiap perlakuan relatif sama. Hal ini berarti bahwa ayam bangkok memberikan respon yang sama terhadap setiap perlakuan.

Kandungan energi dan protein pada ransum sangat menentukan jumlah ransum yang dikonsumsi. Allama (2016) mengajukan bahwa imbangan protein dan energi sangat berpengaruh terhadap jumlah konsumsi ransum, karena energi dalam ransum adalah salah satu pembatas konsumsi. Pernyataan ini sesuai dengan pendapat NRC (1994), bahwa imbangan energi didalam zat makanan dalam ransumakan mempengaruhi konsumsi ransum.

\section{Pengaruh Perlakuan Terhadap Pertambahan Berat Badan.}

Rataan pertambahan berat badan (gram/ekor/hari) dari masing - masing dapat dilihat pada Tabel . Menunjukkan bahwa rataan pengaruh tiga pakan dengan 
level protein yang berbedaterhadap pertambahan berat badan, tertinggi dicapai pada perlakuan RB sebesar 75,52 gr, sedangkan yang terendah di capai pada perlakuan RA sebesar 62,38 gr. Hasil percobaan ini masih dalam kisaran batasan pertambahan berat badan yang di nyatakan oleh Hidayah. dkk (2008), bahwa pertambahan berat badan ayam buras umur 1- 6 minggu yaitu berkisar antara 21,2 -79,5 gr/ekor/hari. Rahayu et al. (2010 ) menyatakan bahwa bobot badan ayam kampung kulit kuning umur delapan minggu adalah $600 \mathrm{~g}$ sedangkan rata rata pertambahan bobot badan adalah $66,6 \mathrm{~g}$.

Berdasarkan hasil análisis keragaman menunjukan bahwa ketiga jenis pakan tidak memberikan pengaruh yang berbeda nyata $(\mathrm{P}>0,05)$. Artinya ketiga pakan dengan level protein yang berbeda sudah memenuhi kandungan zat-zat makanan yang dibutuhkan untuk ayam bangkok.

Pertumbuhan adalah suatu proses peringkatan ukuran tulang, otot,organ dalam dan bagian tubuh yang terjadi sebelum lahir (prenatal) dan setelah lahir (postnatal) sampai mencapai dewasa. Esminger (1992), pertumbuhan dipengaruhi oleh tingkat pemberian makanan, jika makanan cukup dan seimbang kandungan zat-zat di dalamnya maka pertumbuhan akan cepat dan ternak akan mencapai bobot tertentu lebih awal,
Sejalan dengan pendapat. Bell dan Weaver (2002) mengemukakan bahwa faktor yang mempengaruhi pertumbuhan adalah galur ayam, jenis kelamin, dan faktor lingkungan. Tetapi dengan penurunan jumlah konsumsi akan mempengaruhi bobot badan (North 1990). Demikian pula dengan Indarto (2010) menyatakan bahwa untuk mencapai pertumbuhan yang baik dari produksi ayam, ransum yang diberikan harus sempurna dan mencukupi dalam arti ransum yang diberikan harus mengandung semua zat-zat makanan yang diperlukan oleh tubuh dengan kualitas yang baik dalam jumlah yang sesuai dengan kebutuhan. Proses pertumbuhan membutuhkan energi dan substansi penyusun sel atau jaringan yang diperoleh ternak melalui ransum yang dikonsumsinya (Wahju, 1992).

\section{Pengaruh Perlakuan Terhadap Konversi Ransum}

Rataan Konversi Ransum dari masing - masing perlakuan selama penelitian Tabel 4 menunjukan bahwa secara keseluruhan rataan konversi ransum tertinggi dalam perlakuan RA sebesar 1,50 dan konversi ransum yang terendah pada RB sebesar 1,34 nilai konversi ini masih dikatakan baik. Amrullah (2004), menyatakan bahwa konversi ransum yang baik berkisar antara 1,75. Semakin rendah angka konversi ransum berarti kualitas ransum semakin baik. 
Hasil analisis keragaman (Lampiran 3) menunjukan bahwa perlakuan tiga pakan dengan level protein berbeda. Memberikan respon yang samaterhadap konversi ransum.Berdasarkan hasil pembahasan sebelumnya, konsumsi ransum,maupun pertambahan berat badan tidak memberikan pengaruh yang berbeda nyata $(\mathrm{P}>0,05)$. Hal ini yang menyebabkan sehingga nilai konversi ransum juga tidak berbeda nyata karena konversi ransum diperoleh dari hasil pembagian antara konsumsi dan pertambahan berat badan. Konversi ransum yang tidak berbeda nyata menunjukan bahwa tingkat keefisienan ransum untuk menghasilkan daging dengan pertambahan berat badan relatif sama.

Wijayanti (2011) menyatakan bahwa tinggi rendahnya angka konversi ransum disebabkan oleh adanya selisih yang semakin besar atau kecilpada perbandingan antara pakanyang dikonsumsi dengan pertambahan bobot badan yang dicapai. Ditambahkan oleh Fera (2013), beberapa faktor yang mempengaruhi konversi ransum diantaranya bentuk fisik ransum, kandungan nutrisi ransum, lingkugan tempat pemeliharaan, strain, berat badan dan jenis kelamin. Jika konversi ransum semakin besar maka penggunaa ransum kurang efisien. Hyun et al. (1998), semakin rendahnya angka konversi ransum maka menunjukan bahwa ternak tersebut semakin efisien dalam penggunaan ransum yang diberikan.

Data penelitian ini menunjukan bahwa konversi ransum $\mathrm{RB}$ yang mempunyai nilai konversi yang lebih baik dibandingkan dengan ransum RA dan RC, artinya konsumsi ransum pada ransum RA dan RC lebih sedikit tetapi pertambahan berat badannya hampir sama. Sesuai dengan pendapat Mulyono menyatakan bahwa semakin kecil angka konversi ransum berarti semakin efisien atau semakin baik nilai konversinya.

\section{Pengaruh Perlakuan Terhadap Mortalitas}

Kematian anak ayam bangkok selama penelitian berlangsung tercantum pada Tabel 5. Tabel 5, terlihat bahwa selama penelitian tidak terjadi kematian terhadap ayam bangkok dari masing masing perlakuan. Hal ini menunjukan bahwa setiap perlakuan tidak menyebabkan dampak mortalitas. Fatafta (2007) menyatakan bahwa yang perlu diperhatikan untuk menekan angka kematian adalah mengontrol kesehatan ayam, mengontrol kebersihan tempat pakan, dan minum, melakukan vaksinasi teratur, memisahkan ayam yang terkena penyakit dengan ayam yang sehat. Lubis (1992) mengemukakan pada ayam ras pedaging yang mempunyai tingkat protein minimal 19\% yang diberi ransum mengandung $17 \%$ tidak 
Tabel.5. Pengaruh Perlakuan Terhadap Mortalitas Ayam Percobaan Selama Penelitian.

\begin{tabular}{lcccc}
\hline Ransum & Jumlah ayam & $\begin{array}{c}\text { Jumlah anak ayam } \\
\text { yang mati(xi) }\end{array}$ & $\begin{array}{c}\text { Peluang } \\
\text { untuk mati } \\
(\mathrm{Pi})\end{array}$ & (pi xi) \\
\hline RAU1 & 2 & 0 & 0,0000 & 0,0000 \\
RAU2 & 2 & 0 & 0,0000 & 0,0000 \\
RAU3 & 2 & 0 & 0,0000 & 0,0000 \\
RAU4 & 2 & 0 & 0,0000 & 0,0000 \\
RAU5 & 2 & 0 & 0,0000 & 0,0000 \\
RAU6 & 2 & 0 & 0,0000 & 0,0000 \\
RBU1 & 2 & 0 & 0,0000 & 0,0000 \\
RBU2 & 2 & 0 & 0,0000 & 0,0000 \\
RBU3 & 2 & 0 & 0,0000 & 0,0000 \\
RBU4 & 2 & 0 & 0,0000 & 0,0000 \\
RBU5 & 2 & 0 & 0,0000 & 0,0000 \\
RBU6 & 2 & 0 & 0,0000 & 0,0000 \\
RCU1 & 2 & 0 & 0,0000 & 0,0000 \\
RCU2 & 2 & 0 & 0,0000 & 0,0000 \\
RCU3 & 2 & 0 & 0,0000 & 0,0000 \\
RCU4 & 2 & 0 & 0,0000 & 0,0000 \\
RCU5 & 2 & 0 & 0,0000 & 0,0000 \\
RCU6 & 2 & 0 & 0,0000 & 0,0000 \\
& 2 & 0 & 0,0000 & 0,0000 \\
\hline Jumlah & 36 & 0 & 0,0000 & 0,0000 \\
\hline
\end{tabular}

mempengaruhi mortalitas. Dalam hal ini dapat dikatakan bahwa pemberian protein ransum minimal $22 \%$ pada ayam bangkok tidak mempengaruhi mortalitas dan masih dalam tingkat yang aman

\section{KESIMPULAN}

Pemberian pakan dengan level protein berbeda pada ayam bangkok fase starter memberikan hasil yang sama terhadap konsumsi ransum, pertambahan berat badan serta konversi ransum.

\section{DAFTAR PUSTAKA}

Allama, H., O. Sofyan, E. Widodo dan H.S. Prayogi. Pengaruh penggunaan tepung ulat kandang dalam pakan terhadap penampilan produksi ayam pedaging. Jurnal Ilmu Ilmu Peternakan 22(3): 1-8

Amrullah, 2004. Beternak Mandiri,Nutrisi Ayam Broiler. Lembaga Satu Gunung Budi. Bogor

Anggorodi, R. 1990. Ilmu Makanan Ternak Umum. Gramedia Pustaka Utama.

Bell, D. D and W.D. Weaver Jr. 2002. Comercial Chicken Meat and Egg 
Production 5 th Edition. Springer Science and Business Medial Inc.New York.

Fatafta, A.A., dan Z.H.M. Abu-Dieyeh. 2007. Effect of chronic heat strees in broiler performance in Jordan. J. Poultry sci. 6(1): $64-70$

Fera Aryanti, Muh. Bayu Aji, Nugroho Budiono. 2013. Pengaruh pemberian air gula merah terhadap performans ayam kampung pedaging. Jurnal Sains Veteriner 31(2): 156-165

Fahrudin Adirangga, Wiwin Tanwiriah, Heni indrijani. 2017. Konsumsi Ransum, Pertambahan Boot Badan Dan Konversi Ransum Ayam Lokal di Jimmy'S Farm Cipanas Kabupaten Cianjur. Skripsi. Fakultas Peternakan. Universitas Padjadjaran. Bandung.

Hyun, Y., M. Ellis, G. Riskowski. R.W. Johnson. 1998. Grow performance of pigs subjected to multiple concurrent stressors. Jurnal Animal Sci. 76:721-727.

Esminger, M.E. 1992. Poultry Scince .3 nd Edition Interstate Publisher,Inc. Danville.

Indarto, N. 2010 Sukses dan Untung Besar Beternak Ayam Broiler. Agro Media Pustaka. Jakarta.

Lacy, M. \& L. R. Vest. 2000. Improving Feed Convertion In Broiler: A guide for Growers. Springer Science and Business media Inc, New York .

Lubis. 1999. Pengaruh Dua Periode Starter Dan Protein Ransum Yang Berbeda Pada Pertumbuhan Ayam Silangan (Pelung $x$ Kampung).
Seminar Nasional Peternakan dan Veteriner. Hal: 325 - 331.

Mulyono, 1998. Memelihara Ayam Buras Berorientasi Agribisnis. Penerbit Swadaya. Bogor.

National Research Council. 1994. Nutrient Requirements of Poultry Resived edition. National Academic Press, Washington, DC.

North, M. O, dan D.D Bell. 1990. Commercial Chicken Production manual. Ed. The Avi publishing company inc. Wesport, connecticut.

Nurul, H., Risco B Gobel, M. N. Djide, Munif S Hassan. 2008. Pengaruh Penambahan Variasi Konsentrasi Starter Probiotik pada Pakan Terhadap Perkembangan Ayam Kampung (Gallus domesticus). Jurnal Agritek 17: 1-9

Rasyaf, M. 1991. Ayam Lokal. Bogor: Kanisius, Redaksi Argo Media. 2003.

Rahayu B.W.I, A.E.P Widodo dan R. Sarunggalo. 2010. Penampilan pertumbuhan ayam persilangan Kampung dan Bangkok. Jurnal Ilmu Peternakan UNIPA 15(2): 7781.

Tillman, A. D., H. Hartadi, S. Reksohadiprodjo, S. Prawirokusumo dan S. Lehdosoekojo. 1991. Ilmu Makanan Ternak Dasar. Universitas Gadjah Mada Press, Yogyakarta.

Wahju, J. 1992. Nutrisi Unggas. edisi ke-4 Universitas Gadjah Mada. Press, Yogyakarta. 
Wijayanti, R.P. 2011. Pengaruh suhu kandang yang berbeda terhadap performance ayam pedaging periode starter. Jurnal Ilmu - Ilmu Peternakan (Fapet UB) 24(3): 79 87. 